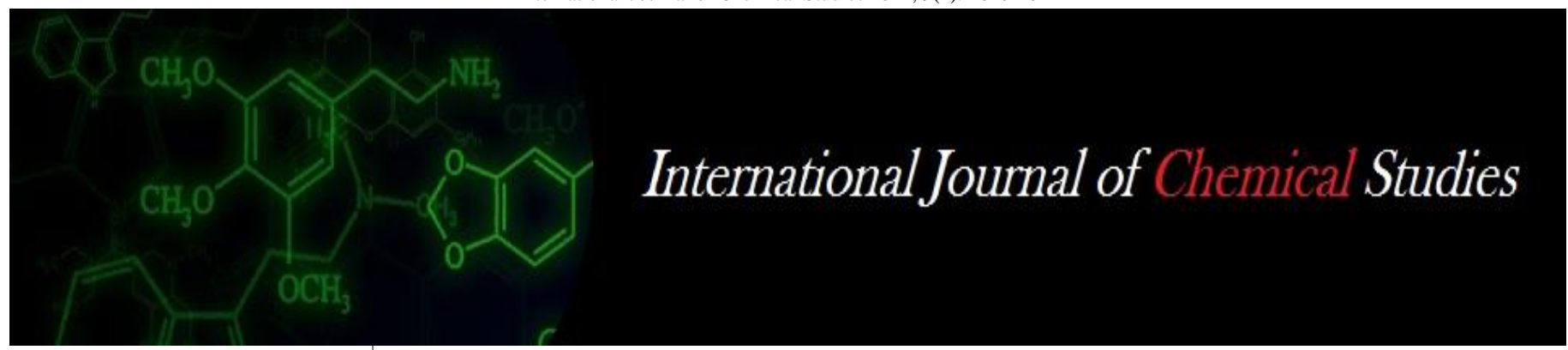

P-ISSN: 2349-8528

E-ISSN: 2321-4902

www.chemijournal.com

IJCS 2021; 9(1): 1610-1612

(C) 2021 IJCS

Received: 17-10-2020

Accepted: 29-11-2020

\section{AN Sannake}

Department of Food Science and Technology, Mahatma Phule Krishi Vidyapeeth, Rahuri,

Maharashtra, India

UD Chavan

Department of Food Science and

Technology, Mahatma Phule

Krishi Vidyapeeth, Rahuri,

Maharashtra, India

\section{SN Godase}

Department of Food Science and Technology, Mahatma Phule

Krishi Vidyapeeth, Rahuri,

Maharashtra, India

\section{PM Kotecha}

Department of Food Science and Technology, Mahatma Phule Krishi Vidyapeeth, Rahuri,

Maharashtra, India
Corresponding Author:

AN Sannake

Department of Food Science and

Technology, Mahatma Phule

Krishi Vidyapeeth, Rahuri,

Maharashtra, India

\section{Studies on preparation of medicinal Shatavari cookies}

\section{AN Sannake, UD Chavan, SN Godase and PM Kotecha}

DOI: https://doi.org/10.22271/chemi.2021.v9.i1w.11457

\begin{abstract}
The present investigation on "Studies on preparation of medicinal (Shatavari) cookies" was undertaken to explore the underutilized or neglected but highly nutrient rich shatavari powder in bakery products. Shatavari powder is a rich source of alcohol, phenolic compounds, alkaloids and can be utilized in bakery products such as cookies. The prepared cookies were analyzed for nutritional composition. The changes occurred during storage of cookies were also studied.

Preliminary experiments were conducted to find out optimum level of shatavari powder for preparation of quality cookies. The quality cookies were prepared from $6 \%$ shtavari powder and $94 \%$ refined wheat flour. Chemical composition of shatavari powder showed that the moisture content was $6.26 \%$, carbohydrates $54.13 \%$, protein $12.18 \%$, fat $0.80 \%$, crude fiber $2.72 \%$, calcium $26.12 \mathrm{mg} / 100 \mathrm{~g}$ and iron $10.17 \mathrm{mg} / 100 \mathrm{~g}$. The fresh cookies had $9.18 \%$ moisture, $15.18 \%$ protein, $26.32 \%$ fat, $3.22 \%$ crude fibre, $72.32 \%$ carbohydrates, $31.22 \mathrm{mg} / 100 \mathrm{~g}$ calcium and $8.16 \mathrm{mg} / 100 \mathrm{~g}$ iron. The sensory evaluation of cookies was carried out regularly at an interval of one month. The mean score for colour and appearance was 8.12 , texture 7.87, flavour 7.81, taste 7.54 and overall acceptability was 7.43 on 9 point hedonic scales. Storage study of cookies showed that the cookies prepared by incorporation of $6 \%$ shatavari powder and 94\% refined wheat flour packed in polypropelyene (PP) and low density polyethylene (LDPE) can be stored up to 3 months in good quality with minimum losses in sensory, nutritional and textural characteristics.
\end{abstract}

Keywords: Preparation, medicinal, Shatavari, cookies, Chemical

\section{Introduction}

Bakery products have become more popular in India since the earlier times. Among the different bakery products cookies constitutes the most popular group. Cookies were invented very early. They could be kept for long time because there moisture content is very low. Cookies are chemically leavened bakery product containing high percentage of fat and sugar (Navy 1980) ${ }^{[4]}$.

Shatavari (Asparagus racemosus Wild) a climbing ayurvedic plant, is known for its numerous activities such as hyperlipidemia, hypertension, angina, dysmenorrhea, anxiety disorders, benign prostatic hyperplasia (BPH), leucorrhoea and urinary tract infections. This plant possesses a wide range of secondary metabolites inclusive of steroids, alkaloids, dihydrophenanthrene derivatives, flavonoids, furan derivatives and essential oils (Singla and Jaitak, 2014) ${ }^{[7]}$.

The shatavari root is useful in treating the ailments like dysentery, tuberculosis and diabetes. Commonly, it supports to maintain the health by giving immunity to diseases. It is considered as very good energy provider to the weak body system (Thakur and Sharma, 2015) ${ }^{[8]}$. In the studies reported above, shatavari can be used in powder form. The utilization of shatavari powder in bakery products particularly in cookies can be done. Therefore an attempt has been made to utilize characteristics of cookies, identifying maximum level of incorporation without adversely affecting the quality of cookies and improving the nutritional characteristics of cookies.

\section{Materials and Methods}

The experiment was conducted in the laboratory of Department of Food Science and Technology, Post Graduate Institute at Mahatma Phule Krishi Vidyapeeth, Rahuri during the year 2019-2020. Shatavari powder was purchased in local market. 


\section{Packaging material}

The packaging materials like polypropylene (PP) and low density polyethylene (LDPE) were purchased from the local market.

\section{Ingredients}

The major ingredients for the preparation of products such as refined wheat flour, sugar and vanaspati ghee were purchased from local market of Rahuri and other chemicals were used from the laboratory store.

\section{Method}

Procedure for preparation of cookies by incorporating shatavari powder

The procedure for preparation of cookies by incorporating shatavari powder is shown in fig. 1 .

Hydrogenated vegetable fat and powdered sugar mixed thoroughly
$\downarrow$
Refined wheat flour + Shatavari powder + Sodium bicarbonate + ammonium bicarbonate
$\downarrow$
Mix both the blends
$\downarrow$
The dough framed into small balls (approx. 10-15g each)
$\downarrow$
Kept in baking trays
$\downarrow$
Baking at $180^{\circ} \mathrm{C}$ for 12 min
$\downarrow$
Cooling and packaging
$\downarrow$

Fig 1: Flow chart for preparation of shatavari cookies

Table 1: Treatment details

\begin{tabular}{|c|c|c|c|c|c|}
\hline Treatments & $\begin{array}{c}\text { Maida } \\
(\boldsymbol{\%})\end{array}$ & $\begin{array}{c}\text { Shatavari } \\
\text { Powder }(\boldsymbol{\%})\end{array}$ & Treatments & $\begin{array}{c}\text { Maida } \\
(\boldsymbol{\%})\end{array}$ & $\begin{array}{c}\text { sshwagandha } \\
\text { powder }(\%)\end{array}$ \\
\hline $\mathrm{T}_{0}$ & 100 & 00 & $\mathrm{~T}_{0}$ & 100 & 00 \\
\hline $\mathrm{T}_{1}$ & 99 & 01 & $\mathrm{~T}_{1}$ & 99 & 01 \\
\hline $\mathrm{T}_{2}$ & 98 & 02 & $\mathrm{~T}_{2}$ & 98 & 02 \\
\hline $\mathrm{T}_{3}$ & 97 & 03 & $\mathrm{~T}_{3}$ & 97 & 03 \\
\hline $\mathrm{T}_{4}$ & 96 & 04 & $\mathrm{~T}_{4}$ & 96 & 04 \\
\hline $\mathrm{T}_{5}$ & 95 & 05 & $\mathrm{~T}_{5}$ & 95 & 05 \\
\hline $\mathrm{T}_{6}$ & 94 & 06 & $\mathrm{~T}_{6}$ & 94 & 06 \\
\hline $\mathrm{T}_{7}$ & 93 & 07 & $\mathrm{~T}_{7}$ & 93 & 07 \\
\hline $\mathrm{T}_{8}$ & 92 & 08 & $\mathrm{~T}_{8}$ & 92 & 08 \\
\hline $\mathrm{T}_{9}$ & 91 & 09 & $\mathrm{~T}_{9}$ & 91 & 09 \\
\hline $\mathrm{T}_{10}$ & 90 & 10 & $\mathrm{~T}_{10}$ & 90 & 10 \\
\hline
\end{tabular}

2.2. Physico-chemical analysis of raw material and cookies The method described in A.A.C.C. $(2000)^{[1,2]}$ for determining moisture was used. The protein content of cookies was estimated by determining total nitrogen content using standard Micro-Kjeldhal method and fat conetnt of the cookies estimated by the soxhlet method A.A.C.C $(2000)^{[1,2]}$. The crude fiber content in the product was estimated by A.A.A.C. (2000) ${ }^{[1,}$ 2]. The carbohydrate content in the selected cookies were obtained by subtracting from 100, the sum of values of moisture, protein, fat, ash and crude fiber content per $100 \mathrm{~g}$ of the sample (Raghuramulu, et al., 1993) ${ }^{[5]}$. Calcium and iron were analyzed using atomic absorption spectrometry (AAS).

\section{Packaging and storage of cookies}

The selected treatment $\left(\mathrm{T}_{6}\right)$ i.e. $6 \%$ of shatavari powder and 96\% refined wheat flour blended cookies was packed in polypropylene (PP) and low density polyethylene (LDPE) and stored for 90 days. The samples were drawn at an interval of 30 days and evaluated for chemical and sensory quality.

Sensory evaluation of cookies prepared by incorporation of shatavari powder

Sensory evaluation of cookies prepared by incorporation of shatavari powder was carried on by 9 point hedonic scale. The average scores of the ten judges for different quality characteristics viz. colour and appearance, flavour, texture, taste and overall acceptability were recorded.

\section{Statistical analysis}

All experiments were carried out by using Factorial Completely Randomized Design (FCRD). The data obtained in the present investigation were analyzed for the statistical significance according to the procedure given by Rangaswamy (2010) ${ }^{[6]}$.

\section{Results and Discussion}

Table 2: Physico-chemical composition of raw materials used in the preparation of cookies

\begin{tabular}{|c|c|c|c|}
\hline $\begin{array}{c}\text { Sr. } \\
\text { No. }\end{array}$ & $\begin{array}{c}\text { Physical and Chemical } \\
\text { constituents }\end{array}$ & $\begin{array}{c}\text { Mean value } \\
\text { (Shatavari } \\
\text { powder) }\end{array}$ & $\begin{array}{c}\text { Mean value } \\
\text { (Refined wheat } \\
\text { flour) }\end{array}$ \\
\hline 1. & Moisture (\%) & 6.26 & 4.16 \\
\hline 2. & Protein (\%) & 12.18 & 11.0 \\
\hline 3. & Fat (\%) & 0.80 & 0.90 \\
\hline 4. & Crude fiber (\%) & 2.72 & 0.72 \\
\hline 5. & Carbohydrates (\%) & 54.13 & 73.9 \\
\hline 6. & Calcium (mg/100 g) & 26.12 & 23 \\
\hline 7. & Iron $(\mathrm{mg} / 100 \mathrm{~g})$ & 10.17 & 2.70 \\
\hline
\end{tabular}

*Each value represents the average of three determinations 
Table 3: Sensory evaluation of cookies prepared by incorporation of shatavari powder

\begin{tabular}{|c|c|c|c|c|c|c|}
\hline \multirow{2}{*}{$\begin{array}{c}\text { Sample } \\
\text { code }\end{array}$} & $\begin{array}{c}\text { Sensory attributes* } \\
\text { Colour and } \\
\text { appearance }\end{array}$ & Texture & Flavour & Taste & $\begin{array}{c}\text { Overall } \\
\text { acceptability }\end{array}$ & Rank \\
\hline $\mathrm{T}_{0}$ & 8.0 & 8.0 & 8.0 & 8.2 & 8.0 & 8 \\
\hline $\mathrm{T}_{1}$ & 8.2 & 8.3 & 8.1 & 8.1 & 8.2 & 7 \\
\hline $\mathrm{T}_{2}$ & 8.2 & 8.3 & 8.3 & 8.3 & 8.3 & 5 \\
\hline $\mathrm{T}_{3}$ & 8.3 & 8.3 & 8.4 & 8.4 & 8.3 & 5 \\
\hline $\mathrm{T}_{4}$ & 8.3 & 8.4 & 8.5 & 8.5 & 8.4 & 3 \\
\hline $\mathrm{T}_{5}$ & 8.7 & 8.5 & 8.6 & 8.5 & 8.4 & 2 \\
\hline $\mathrm{T}_{6}$ & 8.9 & 8.8 & 8.8 & 8.8 & 8.8 & 1 \\
\hline $\mathrm{T}_{7}$ & 8.1 & 8.2 & 8.2 & 8.4 & 8.2 & 6 \\
\hline $\mathrm{T}_{8}$ & 7.4 & 7.8 & 7.8 & 7.8 & 7.9 & 9 \\
\hline $\mathrm{T}_{9}$ & 7.1 & 7.3 & 7.4 & 7.5 & 7.7 & 10 \\
\hline $\mathrm{T}_{10}$ & 7.0 & 7.2 & 7.2 & 7.1 & 7.5 & 11 \\
\hline Mean & 8.03 & 8.10 & 8.15 & 8.18 & 8.19 & - \\
\hline S.E. \pm & 0.01 & 0.01 & 0.03 & 0.03 & 0.01 & - \\
\hline C.D at 5\% & 0.04 & 0.02 & 0.10 & 0.09 & 0.03 & - \\
\hline
\end{tabular}

The organoleptic evaluation of cookies prepared by different combination of shatavari powder and refined wheat flour were carried out. The cookies were prepared and presented to panel of ten judge for assessing the quality and acceptability of product. Organoleptic evaluation of cookies was carried out using a 9 point hedonic scale of sensory characteristics such as colour, texture, taste and overall acceptability. Treatment $\mathrm{T}_{6}$ i.e. $6 \%$ shatavari powder and $94 \%$ refined wheat flour was selected and kept for 3 months for storage study. Chemical analysis and sensory evaluation was done at interval of 30 days.

Table 4: Chemical analysis of shatavari powder and refined wheat flour blended cookies during storage

\begin{tabular}{|c|c|c|c|c|c|c|c|c|}
\hline \multirow{2}{*}{\begin{tabular}{|c|} 
Parameters \\
Chemical constituen
\end{tabular}} & \multicolumn{4}{|c|}{ Initial } & \multicolumn{4}{|c|}{ Final } \\
\hline & T1P1 & T1P2 & T2P1 & $1 \mathrm{~T} 2 \mathrm{P} 2$ & T1P1 & T1P2 & \begin{tabular}{|l|l|}
$\mathrm{T} 2 \mathrm{P} 1$ \\
\end{tabular} & T2P2 \\
\hline Moisture (\%) & 4.11 & 4.11 & 9.18 & 9.18 & 4.31 & 4.35 & 9.38 & 9.40 \\
\hline Protein $(\%)$ & 12.20 & 12.20 & 15.18 & 815.18 & 311.96 & 611.88 & 814.96 & 14.8 \\
\hline Fat $(\%)$ & 25.92 & 25.92 & 26.32 & 26.32 & 20.52 & 0.49 & 26.14 & 26.11 \\
\hline Crude fiber (\%) & 0.80 & 0.80 & 3.22 & 3.22 & 0.64 & 0.61 & 3.08 & 3.04 \\
\hline Carbohydr & 74.70 & 074.70 & 72.32 & 272.32 & 274.55 & 574.53 & \begin{tabular}{|l|l|}
372.16 \\
\end{tabular} & 72.15 \\
\hline Calciu & 22.40 & 22.40 & 31.22 & 231.22 & 22.23 & 322.19 & $\begin{array}{l}931.06 \\
9\end{array}$ & 31.0 \\
\hline Iron $(\mathrm{mg} / 100 \mathrm{~g})$ & 1.70 & 1.70 & 8.16 & 8.16 & 1.54 & 1.48 & 8.01 & 8.00 \\
\hline
\end{tabular}

The data in above Table 4 shows that protein, fat, crude fibre, iron, calcium and carbohydrate contents decreased in T2 with increasing Shatavari powder concentration, this is due to replacing the refined wheat flour which is major source of the protein and fat. Except moisture all other parameters found decreased in final analysis as compared to initial analysis. Cookies stored in low density polyethylene (LDPE) shows better quality than polypropylene (PP).

Changes in sensory parameters of Shatavari powder and refined wheat flour blended cookies during storage

Shatavari powder and refined wheat flour blended cookies (6\% Shatavari powder and 94\% refined wheat flour) remained in good condition at ambient temperature during the entire storage period of 3 months. The cookies stored in low density polyethylene bags (LDPE) showed good quality than polypropylene (PP) during 3 months of storage. The overall acceptability score of ahatavari powder and refined wheat flour blended cookies was decreased from 8.80 to 6.87 in PP and 8.80 to 7.33 in LDPE.

\section{Conclusion}

Shatavari powder and refined wheat flour blended cookies prepared with combination of 6\% shatavari powder and 94\% refined wheat flour was best and it was fairly stable to storage period for chemical composition. The cookies remained in good condition during storage period of 3 month. The cookies stored in LDPE bags showed good quality than polypropylene (PP) during 3 month storage.

\section{References}

1. ACC. Official Methods of Analysis of AACC International, American Association of Cereal Chemists, Washington D.C 2000.

2. OAC. Offical Methods of Analyasis, 18th edition. Association of Official Analytical Chemist. Washignton DC 2000, 454.

3. OAC. Official Methods of Analysis. Howitz (cd) 1980, 734-740.

4. Navy N. Bakery products in the middle east especially in the Arab countries obtained in Egypt. J Food Sci. Technol 1980;22(8):342-347.

5. Raghuramulu N, Nair MK, Kalyanasundaram S. In: A Manual of Laboratory Technique, National Institute of Nutrition, Indian Council of Medical Research, Hyderabad, India 1993, 69-72.

6. Rangaswamy R. A Text Book of Agricultural Statistics, Second edition and New Age International Publishers 2010, 234-458.

7. Singla R, Jaitak V. Shatavari (asparagus racemosus wild): a review on its cultivation, morphology, Phytochemistry and pharmacological importance. International Journal of Pharmacy and Life Sciences 2014;5(3):742-757.

8. Thakur S, Sharma DR. Review on medicinal plant: Asparagus adscendens Roxb. International Journal of Pharmaceutical Science and Health Care 2015;5(3):8297. 